\title{
Does Headedness Affect Processing? A New Look at the V0-OV Contrast
}

\section{Citation}

Polinsky, Maria and Mieko Ueno. 2009. Does headedness affect processing? A new look the VO-OV contrast. Journal of Linguistics 45: 675-710.

\section{Published Version}

http://journals.cambridge.org/action/displayJournal?jid=LIN

\section{Permanent link}

http://nrs.harvard.edu/urn-3:HUL.InstRepos:3322829

\section{Terms of Use}

This article was downloaded from Harvard University's DASH repository, and is made available under the terms and conditions applicable to Open Access Policy Articles, as set forth at http:// nrs.harvard.edu/urn-3:HUL.InstRepos:dash.current.terms-of-use\#OAP

\section{Share Your Story}

The Harvard community has made this article openly available.

Please share how this access benefits you. Submit a story.

Accessibility 
$<$ RECTO $>$

$<\mathrm{CT}>$ Does headedness affect processing?

A new look at the VO-OV contrast ${ }^{1}<\mathrm{FN} 1>$

\author{
$<$ CA $>$ MIEKO UENO \\ University of California, San Diego \\ MARIA POLINSKY \\ Harvard University
}

$<$ DATES $>$ (Received 28 March 2008; revised 2 April 2009)

\title{
$<$ ABSTRACT $>$
}

This paper examines the relationship between headedness and language processing and considers two strategies that potentially ease language comprehension and production. Both strategies allow a language to minimize the number of arguments in a given clause, either by reducing the number of overtly expressed arguments or by reducing the number of structurally required arguments. The first strategy consists of minimizing the number of OVERTLY EXPRESSED ARGUMENTS by using more pro-drop for two-place predicates (Pro-drop bias). According to the second strategy, a language gives preference to one-place predicates over two-place predicates, thus minimizing the number of STRUCTURAL ARGUMENTS (Intransitive bias). In order to investigate these strategies, we conducted a series of comparative corpus studies of SVO and SOV languages. Study 1 examined written texts of various genres and children's utterances in English and Japanese, while Study 2 examined narrative stories in English, Spanish, Japanese, and Turkish. The results for these studies showed that pro-drop was uniformly commoner with two-place predicates than with one-place predicates, regardless of the OV/VO distinction. Thus 
the Pro-drop bias emerges as a universal economy principle for making utterances shorter. On the other hand, SOV languages showed a much stronger Intransitive bias than SVO languages. This finding suggests that SOV word order with all the constituents explicitly expressed is potentially harder to process; the dominance of one-place predicates is therefore a compensatory strategy in order to reduce the number of preverbal arguments. The overall pattern of results suggests that human languages utilize both general (Pro-drop bias) and headedness-orderspecific (Intransitive bias) strategies to facilitate processing. The results on headedness-orderspecific strategies are consistent with other researchers' findings on differential processing in head-final and non-head-final languages, for example, Yamashita \& Chang's (2001) 'longbefore-short' parameterization.

\section{$<\mathrm{A}>1$. INTRODUCTION}

This paper examines the relationship between headedness (as expressed in word order differences) and language processing. It is well-known that languages vary in their word order, and although linguists have different opinions over what criteria should be used to establish the 'basic word order' of a specific language, languages do differ in basic word order no matter how it is defined (cf. Haspelmath et al. 2008). Given this variation, one may wonder what kind of interaction there is between word order and language processing. In particular, do languages of different basic word orders show different processing strategies in terms of comprehension and production, and if so, how?

There have been several suggestions that word order does influence processing. For instance, Yngve (1960) used the notion of the interaction between phrase structure weight and processing load to account for the strong preference in English to place long and complex elements later in the sentence, as in heavy NP shift. For instance, sentences like He gave to the 
girl [a box of candy he got in New York while visiting his parents for ten days around Christmas and New Year's] would be preferred to sentences like He gave [the box of candy he got in New York while visiting his parents for ten days around Christmas and New Year's] to the girl. Yngve argued for a production model in which a phrase structure is generated from top to bottom and left to right, and the processing load at each node is proportional to the number of yet-to-beexpanded nodes (referred to as 'depth') that must be kept in working memory. Heavy NPs in English shift to the right within a sentence, and thus appear at the right edge, because long and potentially deep expressions have to start at the minimum depth, the right-most position, in order to minimize the memory load (see also Wasow 1997).

Hawkins $(1994,1999,2002,2004)$ expanded the notion of phrase structure weight and processing load to account for typological word order preferences, such as pre/postpositions and pre/postnominal relative clauses. He argued that the language processor prefers to have a mother node and all its immediate constituents (e.g. V and NP for VP) recognized as quickly as possible either phrase-initially or phrase-finally, and that those word orders that are optimal for such comprehension constraints are grammaticalized into the most unmarked and frequent constructions in a given language.

More recently, Yamashita \& Chang (2001), taking an experimental approach, showed that in Japanese, in contrast to English, long phrases tend to shift in front of shorter phrases in production. Yamashita \& Chang argued that since Japanese is a verb-final free word order language, it allows speakers to use word order to mark the conceptual saliency of long and complex phrases by fronting them, whereas English has a strict word order and puts a higher value on the syntactic constraint of fronting shorter and more readily accessible phrases. 
This paper extends this line of research by examining what types of strategies are used to ease the processing load associated with languages of different word orders. While earlier studies have focused primarily on gradient phenomena, sensitive to weight or information structure, our main interest here is in the deployment of structural phenomena available to a given language, in particular pro-drop and valency alternations. With this in mind, we conducted two comparative corpus studies of VO and OV languages to investigate such strategies. Study 1 compares English and Japanese and Study 2 examines Spanish and Turkish in addition to English and Japanese.

\section{$<\mathrm{B}>1.1$ Proposed strategies: Pro-drop bias and Intransitive bias}

We propose two strategies that may be used to facilitate language processing, namely, the Prodrop bias and the Intransitive bias, as defined in (1).

\section{$<\mathrm{NL}$; follow copy short lines $>$}

(1) Strategies that aid processing

(a) Pro-drop bias

Minimize the size of the utterance by using fewer overt expressions: use more pro-drop with two-place predicates in both SVO and SOV languages.

(b) Intransitive bias

Minimize structural constraints: reduce the argument-assigning domain by having fewer valencies. SOV languages use a higher proportion of one-place predicates than SVO languages to reduce the number of preverbal arguments.

These two strategies can be motivated theoretically in terms of both language comprehension and production. As regards comprehension, we assume that structures that are optimal for 
comprehenders become grammaticalized (cf. Hawkins 1994, 2002). Those configurations that are optimal for producers may also be grammaticalized. Not only is there some evidence that speakers produce structures that are easier for their addressees (e.g. Haywood, Pickering \& Branigan 2005), but there is also research suggesting that speakers produce whatever is simplest for themselves (e.g. Ferreira \& Dell 2000). Therefore, language producers may do two things: (i) they may follow the strategies for ease of comprehension that have become the internalized properties of the language, and (ii) they may adopt strategies that are easier for themselves (which may also have been grammaticalized). We discuss below how the biases we propose can be motivated based on their potential for easing comprehension and production, in connection to some relevant previous studies.

The Pro-drop bias (1a) is a general processing economy principle that applies to a language of any word order, in that it should be easier to comprehend and produce fewer overt arguments. We make two assumptions in postulating this strategy. First, we assume that recovering null pronouns is not costly to the listener. This assumption is based on studies showing that null pronouns in fact are highly recoverable in discourse, in that their referents tend to have been previously-mentioned and to be highly-ranked in the current and previous utterances - that is, they exhibit syntactic and pragmatic features such as being the topic or subject, or they are highly salient, and are thus at the center of the speaker's attention (Kameyama 1985, 1988; Walker, Iida \& Cote 1994; Turan 1998; Prince 1999). Second, we assume that dropping a pronoun is easier for a speaker than producing an overt pronoun, since it seems natural that overtly articulating something would take more cognitive resources than not doing so. Syntactic priming evidence suggesting that producers build syntactic structures only with overt arguments (Yamashita, Chang \& Hirose 2005) supports this assumption. 
Possibly related to the Pro-drop bias, P. Bloom (1990) reports that VP length in Englishspeaking children's utterances increases as a function of subject type - schematically, VP with a full NP subject $<$ VP with a pronominal subject $<$ VP with a null subject - and attributes this to a performance limitation of children, in that young children are not capable of producing long utterances. If we translate 'shorter utterances' into ‘fewer overt arguments', Bloom's data become relevant to the ease of production strategy discussed here. Although adults do not have the same performance limitations as children, they may still prefer shorter utterances over longer utterances.

As we will discuss in section 4.1, the presence of Pro-drop bias has in fact already been observed in various published data, including a corpus of spoken Spanish (SVO with rich verb agreement) by Bentivoglio (1992), a corpus of spoken Mandarin (SVO with no verb agreement) by Tao (1996), and a corpus of spoken Sacapultec Maya (an ergative VOS language with rich verb agreement) by Du Bois (1987). In addition, there appears to be a Pro-drop bias in child English (L. Bloom 1970, Braine 1976, Mazuka et al. 1986, P. Bloom 1990), in that children tend to omit more subjects in two-place predicates than in one-place predicates. This study aims to test if the Pro-drop bias also holds for SOV languages in addition to SVO languages.

The Intransitive bias (1b) is based on the idea that since $\mathrm{V}$ comes later in the string for SOV than for SVO languages, the processing of SOV languages should be more difficult compared to that of SVO languages with regard to the distance needed to reach the argumentassigning verbal head. In the sentence comprehension literature, the verb is often argued to play a crucial role in parsing decisions. For instance, it is at the verb position that the parser determines how other elements of the sentence, such as a dislocated wh-filler, are interpreted (Pickering \& Barry 1991, Gibson \& Hickok 1993, Gorrell 1993, Pickering 1993). The parser also 
utilizes information about how likely a given verb is to take an NP or sentential complement (Trueswell, Tanenhaus \& Kello 1993, Garnsey et al. 1997). This centrality of the verb is captured by Pritchett's (1992) head-driven parser model, which argues that syntactic attachment happens at a verbal head. Since in an SOV language the parser has to hold both S and O in memory until it has reached $\mathrm{V}$, as opposed to holding only $\mathrm{S}$ in memory in SVO languages, SOV constructions plausibly should carry an extra processing cost in comparison to SVO constructions. As a result, SOV languages could be expected to use more instances of SV (intransitive, one-place) structures than SVO languages in order to minimize the effects of this structural constraint.

It must be noted, however, that the head-driven parser model has recently been called into question on the basis of evidence that sentence comprehension is more incremental in nature than Pritchett's model supposes (e.g. Kamide \& Mitchell 1999, Kamide, Altmann \& Haywood 2003, Aoshima, Phillips \& Weinberg 2004). Still, we cannot completely dismiss the importance of verbal heads in parsing operations, and having a verb appear later rather than sooner could well present a significant enough processing challenge to warrant compensatory strategies. For instance, incremental processing models argue that a range of cues are utilized to incrementally build a sentence. One of those cues is case-marking, which allows for the early determination of the thematic role and grammatical function of each nominal argument before the parser reaches the clause-final verb position. We therefore argue that overt case-marking is a strategy that compensates for the late appearance of V in SOV languages. This is consistent with Greenberg's (1966) classic claim that if in a language SOV is the dominant order, the language almost always has a case system (Universal 41). And indeed, of the many SOV languages, only a small number do not have overt case-marking, Abkhaz being the usual notable example (Hewitt 1979). On the 
other hand, SVO languages often have little or no overt case-marking; the percentage of SVO languages without overt case-marking is much higher than that of SOV languages (Siewerska 1996, Comrie 2008). In addition to case-marking, we argue that the reduction of preverbal arguments (through creating intransitive structures) is another example of a compensatory strategy - a claim we test empirically and describe in the following sections.

As for production-based motivations for the Intransitive bias, recall Yngve's (1960) 'depth' account, whereby expanding a node on the left side of the sentence (= deeper node), with more nodes yet to be expanded, is more costly than expanding a node on the right side of the sentence; this is why it is preferable to shift a long direct object from the left side to the right side of the sentence in heavy NP shift in English. Following Yngve's arguments, having an object NP on the left side of the verb involves a higher production cost in an SOV language than having an object NP on the right of the verb does in an SVO language. But if a one-place SV predicate were to be used instead of an SOV predicate, then there would be no such extra production cost. In addition to this phrase-structural account, it may well be that it is generally easier to produce fewer overt NPs before the verb. Lindsley (1975) reports that when English-speaking participants were instructed to describe a picture they were presented with (showing the subject referent in action or the subject referent only), they took the same amount of time to initiate a transitive sentence as they did to initiate an intransitive sentence, but a shorter time to say the word denoting the subject only. He concludes that speakers start their utterances before they have syntactically encoded the object of a transitive action but not before they have chosen the verb. If the verb in a predicate carries the most amount of information (in terms of grammatical functions and thematic roles, also for production as in for comprehension), then producers might benefit by getting to the heaviest information (i.e. the verb) as soon as possible and getting it out 
of the utterance by minimizing the preverbal materials. ${ }^{2}<\mathrm{FN} 2>$ It would thus be less costly to produce SV than SOV.

$<\mathrm{B}>1.2$ Predictions

In summary, based on the Pro-drop bias hypothesis, we predict that both SVO and SOV languages reduce processing load by reducing the number of overt arguments through the use of pro-drop, and more so with two-place predicates than with one-place predicates. In addition, based on the Intransitive bias hypothesis, we predict that SOV languages reduce processing load by reducing the number of preverbal arguments, and should therefore utilize more one-place predicates than SVO languages do.

$<\mathrm{A}>2$. STUDY 1

In order to test our hypotheses, Study 1 compared sentences from English (an SVO language) and Japanese (an SOV language) from various genres.

$<\mathrm{B}>2.1$ Methods

$<\mathrm{C}>2.1 .1$ Materials

A total of 2,400 sentences from four genres in both English and Japanese (300 sentences/genre $\times$ 4 genres $\times 2$ languages) were analyzed for predicate type. The four genres were home decoration magazines, mystery novels, books about Japanese politics, and children's utterances from CHILDES (mean age around 3;8) (see the data source references at the end of the paper for full citations).

\section{$<\mathrm{C}>2.1 .2$ Procedures}

Sentences were manually coded for predicate type by a Japanese graduate student in syntax at University of California, San Diego, ${ }^{3}<$ FN3 $>$ who was unaware of the purpose of the study, and then checked by the first author. Only the matrix clause of the sentences was coded; in order to 
avoid possible differences between matrix and subordinate structures, adjoined/conjoined and embedded clauses were not considered. Relative clauses modifying an argument in the matrix clause were considered part of the relevant NP, but their internal structure was not considered (cf. (2c) and (3a)). Complement clauses in argument position were treated as being on a par with non-clausal arguments (cf. (3b)).

Matrix clauses were classified as 'one-place predicates', 'two-place predicates', or 'sentence fragments'. The category labeled 'one-place predicates' included intransitives, nonverbal predicates (adjectival and nominal), and passives (with or without the by-phrase). 'Twoplace predicates', or more accurately '2+-place predicates', encompassed transitives and ditransitives. For the purposes of this study, the main contrast of interest was between one-place and 2+-place predicates, which is why we made a decision to collapse 'transitives' and 'ditransitives' into a single category. 'Sentence fragments' include bare NPs and interjections.

Examples of one-place predicates in English and Japanese are shown in (2).

$<\mathrm{NL}$; please follow copy word-for-word alignment (up to 4 lines) in Japanese examples in exx. (2)-(5); follow copy extra line-spacing for better legibility; place example annotations at the right margin.>

(2) One-place predicates

(a) Intransitives

S V

Sometimes they died.

(English - mystery novel \#7) 
$\begin{array}{lll} & \mathrm{S} & \mathrm{V} \\ \text { 思いがけず、 } & \text { 涙が } & \text { こみあげてきた。 } \\ \text { omoigakezu } & \text { namida-ga } & \text { komiagete-kita. } \\ \text { unexpectedly } & \text { tear-NOM } & \text { came.out }\end{array}$

'Tears came out unexpectedly.' (Japanese - mystery novel \#16)

(b) Non-verbal predicates

S Adj

He's bigger.

(English - children's utterance \#88)

$\begin{array}{lll}\text { ほら、こっちが } & \text { NP } \\ \text { 火事やて。 } \\ \text { hora, kocchi-ga } & \text { kaji-yate } \\ \text { look } & \text { here-NOM } & \text { fire-be }\end{array}$

'Look, here is the fire.'

(Japanese - children's utterance \#184)

(c) Passives

$\mathrm{S} \quad \mathrm{pV}$

Few wood cabinets are constructed of solid wood.

(English - home decoration magazine \#61)

$\begin{array}{llll}\text { 分厚い } & \text { 木の } & \text { ドアには } & \text { 職人さんの } \\ \text { buatsui } & \text { ki-no } & \text { doa-ni-wa } & \text { shokuninsan-no } \\ \text { thick } & \text { wood-GEN } & \text { door-DAT-TOP craftsman-GEN }\end{array}$

$\mathrm{S} \quad \mathrm{pV}$

手作りになる 鉄の 金具が付けられています。

tezukurininaru tetsu-no kanagu-ga tsukerarete imasu.

be.handmade iron-GEN metal-NOM attached be

'An iron metal handmade by a craftsman is attached to a thick wooden door.'

(Japanese - home decoration magazine \#202)

(3) shows examples of two-place and higher predicates in English and in Japanese. In assembling corpus statistics, we did not make a distinction between NP and sentential complements; they were all counted as 'objects'. 


\section{(3) Two-place predicates}

(a) Transitives with NP complements

$$
\mathrm{S} \quad \mathrm{O}
$$

These dimensions represent cultural continua, not dichotomies, and the differences are in degree, not in kind.

(English - book about Japanese politics \#8)

たとえば、鈴木内閣と tatoeba suzukinaikaku-to for.example Suzuki.ministry-with
同じように、高い 支持率の onajiyouni takai shijiritsu-no same.as high support.rate-GEN

$\begin{array}{lllll} & & & & S \\ \text { もとで } & \text { 船出した } & \text { 池田内閣 } & \text { 当初の } & \text { 状況が } \\ \text { Motode } & \text { funadeshita } & \text { ikedanaikaku } & \text { tousho-no } & \text { joukyou-ga } \\ \text { under } & \text { sailed } & \text { Ikeda.ministry } & \text { first.time-GEN } & \text { situation-nom }\end{array}$

$\begin{array}{llll}\text { O } & & \mathrm{V} \\ \text { このことを } & \text { よく } & \text { 示して } & \text { いる。 } \\ \text { konokoto-o } & \text { yoku } & \text { shimeshite } & \text { iru } \\ \text { this-ACC } & \text { well } & \text { indicating } & \text { is }\end{array}$

'For example, the initial situation of the Ikeda ministry, which sailed out under a high support rate just like the Suzuki ministry, indicates this well.'

(Japanese - book about Japanese politics \#20)

(b) Transitives with sentential complements

\section{S V O}

You said I could go.

S

犬も pro pro

inu-mo

dog-also
$\mathrm{O}$ 乗りたいなあて noritaina-te want.to.ride-that
(English - children's utterance \#25)

\section{$\mathrm{V}$}

ゆうとおる。 yutooru.

is.saying

'The dog is also saying that (he) wants to ride (it).'

(Japanese - children's utterance \#227)

(c) Ditransitives

$\mathrm{S}$

Cool colors - such as mint green or sky blue - give a room a fresh, airy ambiance.

(English - home decoration magazine \#215) 


\begin{tabular}{|c|c|c|c|c|}
\hline & & $\mathrm{S}$ & & \\
\hline バリ島の & 高級 & バンブー & 家具が、 & 涼しげな \\
\hline $\begin{array}{l}\text { barito-no } \\
\text { Bali.island-GEN }\end{array}$ & $\begin{array}{l}\text { kokyu } \\
\text { high-class }\end{array}$ & $\begin{array}{l}\text { banbu } \\
\text { bamboo }\end{array}$ & $\begin{array}{l}\text { kagu-ga } \\
\text { furniture-NOM }\end{array}$ & $\begin{array}{l}\text { suzushigena } \\
\text { cool }\end{array}$ \\
\hline
\end{tabular}

$\begin{array}{lll}\mathrm{O} & \mathrm{O} & \mathrm{V} \\ \text { ナチュラル感を } & \text { 部屋に } & \text { 運んでくれます。 } \\ \text { nachurarukan-o } & \text { heya-ni } & \text { hakondekuremasu. } \\ \text { natural.feeling-ACC } & \text { room-DAT } & \text { bring }\end{array}$

'The high-class bamboo furniture from Bali Island brings the room a cool natural feeling.'

(Japanese - home decoration magazine \#278)

When coding Japanese sentences, all nominative-marked NPs were coded as subjects, but constructions that arguably contained nominative-marked objects were also tallied. ${ }^{4}<\mathrm{FN} 4>\mathrm{We}$ distinguish three main types of such constructions (see also Takezawa 1987):

$<\mathrm{NL}$; follow copy numbering $>$

(i) 'existential-possessive constructions', with the possessor in the dative case and the possessee in the nominative, as in (4a)

(ii) 'potential constructions', with the subject in the dative case and the theme in the nominative (Dubinsky 1993), as in (4b)

(iii) 'need constructions', with the agent in the dative case and the theme in the nominative, as in $(4 c)$.

$<\mathrm{NL}>$

(4) Constructions with nominative-marked objects

(a) Existential-possessive construction

$\begin{array}{lllll}\text { 木の } & \text { 皮や } & \text { 枯れ枝 } & \text { などの } & \text { 植物には } \\ \text { ki-no } & \text { kawa-ya } & \text { kareeda } & \text { nado-no } & \text { shokubutsu-ni-wa } \\ \text { tree-GEN } & \text { bark-and } & \text { withered.branch } & \text { etc.-of } & \text { plant-DAT-TOP }\end{array}$


乾いた ぬくもり感が あります。

Kawaita nukumorikan-ga arimasu

dry warmth-NOM exist

'Some plants, such as wooden bark and withered branches, have dry warmth.'

(lit.: 'For some plants such as wooden bark and withered branches, dry warmth exists.')

(Japanese - home decoration magazine \#231)

(b) Potential construction

$\begin{array}{lllll}\text { 夫が } & \text { いわんと } & \text { している } & \text { ことが、 } & \text { にわかには } \\ \text { otto-ga } & \text { iwanto } & \text { shiteiru } & \text { koto-ga } & \text { niwakani-wa } \\ \text { husband-NOM } & \text { say } & \text { be.going.to } & \text { thing-NOM } & \text { instantly-TOP }\end{array}$

信じられなかった。

shinji-rare-na-katta.

believe-able-not-PAST

'(I) could not instantly believe what (my) husband was going to say.'

(lit.: 'What (my) husband was going to say was not instantly believable.')

(Japanese - mystery novel \#80)

(c) 'Need' construction

\begin{tabular}{|c|c|c|c|}
\hline $\begin{array}{l}\text { 選挙に } \\
\text { senkyo-ni } \\
\text { election-DAT }\end{array}$ & $\begin{array}{l}\text { 出馬し } \\
\text { shutsubashi } \\
\text { run }\end{array}$ & $\begin{array}{l}\text { 当選を } \\
\text { tousen-o } \\
\text { winning-ACC }\end{array}$ & $\begin{array}{l}\text { 期する ためには、 } \\
\text { kisuru tame-ni-wa } \\
\text { expect in.order-DAT-TOP }\end{array}$ \\
\hline $\begin{array}{l}\text { 巨額の } \\
\text { kyogaku-no } \\
\text { large.sum-of }\end{array}$ & $\begin{array}{l}\text { 資金が } \\
\text { shikin-ga } \\
\text { fund-NOM }\end{array}$ & $\begin{array}{ll}\text { 必要と } & \text { な } \\
\text { hitsuyoto } & \text { na } \\
\text { necessary } & \text { be }\end{array}$ & $\begin{array}{l}\text { った。 } \\
\text { tta. } \\
\text { came }\end{array}$ \\
\hline
\end{tabular}

'In order to run for election and expect to win, (they) came to need a large sum of money.'

(lit.: 'In order to run for election and expect to win, a large sum of money became necessary.')

(Japanese - book about Japanese politics \#99)

Occurrences of both subject and object pro-drop were also recorded in child English and in all the genres of Japanese (a pro-drop language), as seen in (5). Although adult English is not considered to be a pro-drop language, we included the child English data because child English shows a much broader use of pro-drop (L. Bloom 1970, Braine 1976, Mazuka et al. 1986, P. 
Bloom 1990) compared to adult English, which exhibits pro-drop only in a few restricted cases (imperatives, ‘diary-drop': cf. Haegeman 1990, Rizzi 1994). ${ }^{5}<$ FN5 $>$ Imperatives were not included here as cases of pro-drop.

$<\mathrm{NL}>$

(5) Pro-drop examples

(a) S(subject)-drop only

Nope pro gone shopping

$\begin{array}{llllll}\text { pro } & \text { 僕に } & \text { 向かって、一目散に } & \text { 走って } & \text { 来たんです。 } \\ \text { boku-ni } & \text { mukatte } & \text { ichimokusanni } & \text { hashitte } & \text { kitandesu. } \\ \text { me-DAT } & \text { toward } & \text { for.one's.life } & \text { running } & \text { came }\end{array}$

'(She) came running toward me for her life.'
(English - children's utterances \#169)

(Japanese - mystery novel \#11)

(b) $\mathrm{SO}$ (subject and object)-drop

no examples attested in the English corpus

$$
\begin{array}{cll}
\text { pro もう pro } & \text { 出したん? } \\
& \begin{array}{l}
\text { mou } \\
\text { already }
\end{array} & \text { dashitan? } \\
& \text { got.out }
\end{array}
$$

'Have (you) already got (it) out?'

(c) O(object)-drop only

Her's gonna make pro

(English - children's utterances \#37)

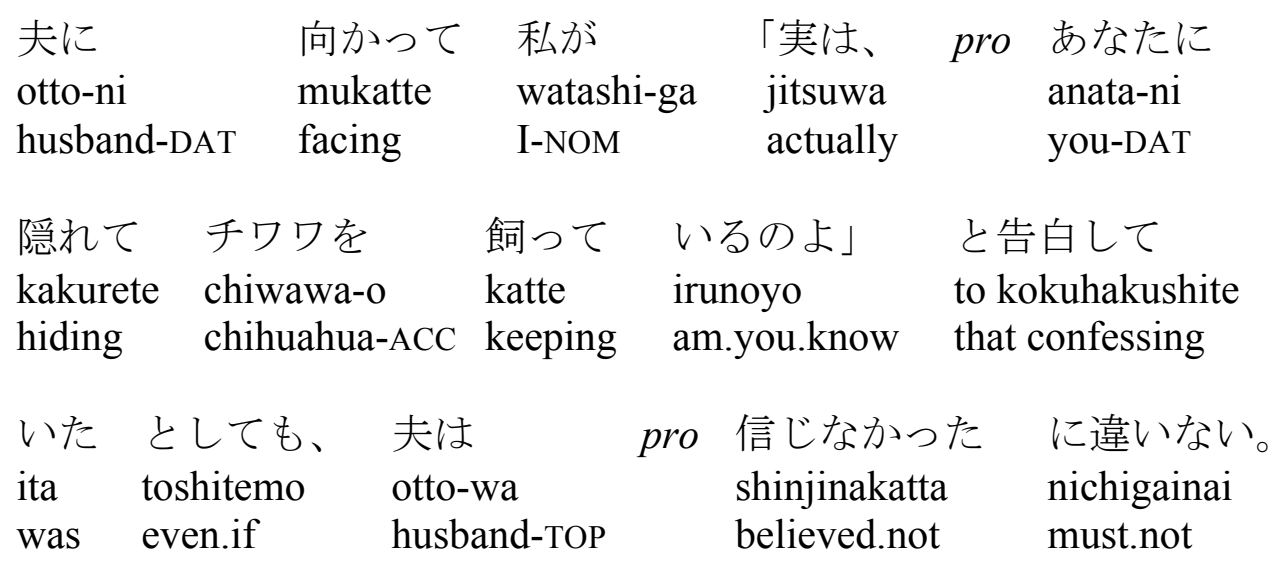


'Even if I confessed to (my) husband, "Actually (I) am keeping a chihuahua behind your back", (my) husband would not have believed (it).'

(Japanese - mystery novel \#253)

For each language, the number of sentence tokens of each classification category in each genre, such as 'two-place predicates in the Japanese mystery genre', was tallied. A separate count of the number of sentence tokens with null arguments was also tallied for each predicate type,${ }^{6}<$ FN6 $>$ genre, and language.

In order to test the Pro-drop bias, we used a Pearson chi-square test to analyze the sentence tokens with and without pro-drop for either one-place or two-place predicates for each genre and each language to determine whether their distributions were significantly different. The point at issue was to test whether either language would show a higher rate of pro-drop with two-place than one-place predicates. In addition, details of pro-drop types (e.g. S-drop only, Odrop only) and types of null subject arguments (1st, 2nd, 3rd person) were recorded.

In order to test the Intransitive bias, the occurrences of one-place and two-place predicates for the two languages were placed into a two-by-two table (English vs. Japanese, oneplace vs. two-place) for each genre and examined by a Pearson chi-square test to determine whether there was a significantly different distribution of one-place and two-place predicates between the two languages. Here the point was whether Japanese would have a higher percentage of one-place predicates than English. In addition, the constructions with arguably nominative-marked objects (see (4) above) were counted separately, and separate chi-square tests were run treating those constructions as two-place instead of one-place predicates, in order to see if coding these predicates differently would make any statistical difference in the one-place vs. two-place distribution between English and Japanese tested above. Further, different types of one-place predicates, such as 'passives' and 'intransitives', were counted separately to see 
whether there was any difference in the proportions of these predicate types between English and Japanese. An alpha level of .05 was used for all statistical tests.

$<\mathrm{B}>2.2$ Results

\section{$<\mathrm{C}>2.2 .1$ Pro-drop bias}

Figure 1 shows the distribution of pro-drop for one-place vs. two-place predicates in child English, which shows a significantly higher percentage of pro-drop with two-place predicates than with one-place predicates [one-place vs. two place: $3 \%$ vs. $\left.19 \%, \chi^{2}(1)=13.20, p<.001\right]$.

$<$ Figure 1 about here $>$

Figure 2 shows the distribution of pro-drop with one-place vs. two-place predicates in Japanese. When collapsed across genres, Japanese also shows a significantly higher percentage of pro-drop with two-place predicates than with one-place predicates [one-place vs. two place: $21 \%$ vs. $\left.38 \%, \chi^{2}(1)=31.62, p<.001\right]$. This is also true for all but one of the genres separately [one-place vs. two place, home decoration: $21 \%$ vs. $52 \%, \chi^{2}(1)=22.70, p<.001$; politics: $6 \%$ vs. $26 \%, \chi^{2}(1)=24.19, \mathrm{p}<.001 ;$ children: $49 \%$ vs. $\left.79 \%, \chi^{2}(1)=11.32, \mathrm{p}<.001\right]$; the exception is mystery novels, which follow the trend numerically, but the difference is not statistically significant [one-place vs. two place: $21 \%$ vs. $\left.25 \%, \chi^{2}(1)=.63, p=.428\right]$. In summary, as shown in figures 1 and 2, two-place predicates tend to involve more instances of pro-drop than oneplace predicates for both child English and Japanese, consistent with the Pro-drop bias.

\section{$<$ Figure 2 about here $>$}

Table 1 shows the details of pro-drop types. For both languages, the majority of instances of pro-drop are S(ubject)-drop (child English 62\%, Japanese total 90\%). Other cases include O(bject)-drop only for child English (38\%) and SO-drop (8\%) and O-drop only (3\%) for Japanese. ${ }^{7}<$ FN7 $>$ 


\section{$<$ Table 1 about here $>$}

Table 2 shows the types of null subject arguments. Null subjects for first and second person referents are dominant in child English $(1 s t+2 n d: 56 \%)$, while null subjects for third person referents were dominant in Japanese $(1 s t+2 n d$ total: $29 \%)$. All of the third person referents are animate in child English, while most of the third person referents are inanimate in Japanese. All of the referents appear to be entities that had been previously mentioned in the discourse, and they refer to the speaker or the addressee at the rate given above for each language; thus, it seems more natural that they would be pronouns/demonstratives if overtly expressed, rather than lexical NPs, due to their discourse salience.

\section{$<$ Table 2 about here $>$}

Table 3 shows the types of null object arguments. Here, unlike null subjects, all of the referents of the null objects for all the genres in both languages were inanimate third person - the only exception being one animate third person object in the mystery genre in Japanese. All of the referents again appear to be previously-mentioned information in the discourse, which would seem more likely to be overtly expressed as pronouns/demonstratives rather than as lexical NPs.

\section{$<$ Table 3 about here $>$}

\section{$<\mathrm{C}>2.2 .2$ Intransitive bias: one-place vs. two-place predicates}

Figure 3 shows the distribution of sentence tokens for one-place vs. two-place predicates in English and Japanese. When collapsed across genres (see the upper part of figure 3), Japanese exhibits a significantly higher percentage of one-place predicates than English does [E(nglish) vs. $J($ apanese $): 51 \%$ vs. $\left.73 \%, \chi^{2}(1)=107.13, \mathrm{p}<.001\right]$. When each genre is examined separately, this is also the case for all the genres except for books about Japanese politics [home decoration: E $42 \%$ vs. J $81 \%, \chi^{2}(1)=89.59, p<.001 ;$ mystery: E $49 \%$ vs. J $65 \%, \chi^{2}(1)=13.73, p<.001$; 
children: E $41 \%$ vs. J 76\%, $\chi^{2}(1)=44.90, \mathrm{p}<.001$; politics: E $68 \%$ vs. J $71 \%, \chi^{2}(1)=.58, \mathrm{p}$ $=.447]$. Notice that the English discussion of Japanese politics shows a much higher percentage of one-place predicates (68\%) than other genres (home decoration: 42\%, mystery: 49\%, children: 41\%). By contrast, Japanese has a smaller inter-genre difference (range of one-place predicates in Japanese: $65 \%-81 \%$ ).

\section{$<$ Figure 3 about here $>$}

Table 4 shows the number of constructions that include what are arguably nominativemarked objects in Japanese (see footnote 4). We can see that such sentence tokens are fairly infrequent: only 76 tokens or $6 \%$ of the total number of the Japanese sentences examined contain arguably nominative-marked objects.

\section{$<$ Table 4 about here $>$}

Even when these constructions are counted as two-place predicates instead of one-place predicates, Japanese still exhibits a significantly higher percentage of one-place predicates than English does when collapsed across genres [E 51\% vs. J 65\%, $\left.\chi^{2}(1)=46.22, \mathrm{p}<.001\right]$. When each genre is examined separately, this holds true for home decoration magazines [E $42 \%$ vs. J $\left.72 \%, \chi^{2}(1)=52.60, p<.001\right]$ and children's utterances $\left[E 41 \%\right.$ vs. $J 74 \%, \chi^{2}(1)=41.58, p$ $<.001$ ], with mystery novels showing a marginal trend [E 49\% vs. J 56\%, $\chi^{2}(1)=2.88, \mathrm{p}=.090$ ]. The politics genre again shows no significant difference between the two languages [E $68 \%$ vs. J $\left.63 \%, \chi^{2}(1)=1.98, p=.159\right]$

\section{$<$ Table 5 about here $>$}

Table 5 shows the breakdown of one-place predicate types. Collapsed across genres, the higher ratio of one-place predicates over two-place predicates in Japanese appears to be due to there being more instances of non-verbal predicates (English 299 vs. Japanese 429) and 
intransitives (English 151 vs. Japanese 295) in Japanese than in English. When individual genres are examined, Japanese exhibits a higher percentage of non-verbal predicates than English in the home decoration, politics, and children's utterances genres, and intransitives show the same pattern in home decoration, mystery, and politics. Interestingly, more passive sentences are used in English (105 in total) than in Japanese (37 in total) in all the genres. The politics genre includes many more passive tokens (82) in English than in Japanese (27), and this seems to have made the total number of one-place predicates in both languages roughly equivalent within that genre, as discussed above with respect to figure 3 .

\section{$<\mathrm{B}>2.3$ Study 1: preliminary discussion}

The overall pattern of results in Study 1 was consistent with both of our hypotheses, namely, that pro-drop is more likely to occur with two-place predicates than with one-place predicates for both an SVO language and an SOV language, and that an SOV language tends to use more intransitive structures than an SVO language. In addition to typical pro-drop SVO languages (Spanish, Chinese) discussed in the Introduction, our results suggest that children's utterances in English also exhibit a Pro-drop bias, consistent with previous reports (L. Bloom 1970, Braine 1976, Mazuka et al. 1986, P. Bloom 1990). Japanese also supports the Pro-drop bias hypothesis and shows more instances of pro-drop with two-place predicates than with one-place predicates, as demonstrated in Figure 2. Recall that in the Introduction we assumed that processing a covert pronoun would not be hard because of the high recoverability of the referent. Our data in Study 1 suggest that in both child English and Japanese, the omitted arguments typically map onto previously mentioned information that is easily identifiable from the discourse (see section 2.2.1 above). Thus we continue to assume that recovering null pronouns is not costly, and that the 
reduction of overt argument NPs by pro-drop facilitates the processing of both SVO and SOV sentences.

As predicted by the Intransitive bias hypothesis, one-place predicates were more frequent in Japanese than in English. The only exception to this pattern was observed in the sub-corpus of texts about Japanese politics, which had approximately equal instances of one-place predicates in both languages. This seems to be due in large part to the high number of passive constructions in the English data, which is probably because in English the use of passive is more common in academic writing than in other genres (cf. Svartvik 1966).

Therefore, our preliminary conclusion is that English and Japanese indeed seem to utilize strategies to facilitate processing by minimizing the number of overt arguments by pro-drop (for both child English and all genres of Japanese) and also by preferring intransitive structures which minimize structural constraints (for Japanese).

However, some questions still remain. The first is whether the pattern of results found in Study 1 will hold for other SVO and SOV languages. Since Japanese is (thus far) the only SOV language for which we have data concerning the Pro-drop bias, it is necessary to test another SOV language. Similarly, since we only have data points for English and Japanese for the Intransitive bias, we need to test more SVO and SOV languages. Second, the sentences in Study 1 were matched for genre, which means that they had similar, though not identical, content; additionally, the sentences in a given genre in a given language were produced either by one speaker or by a few (at most three) speakers. Therefore, the results may have been skewed by content and by individual speaker variation. We address these questions in Study 2.

$<$ A $>3$. STUDY 2 
Study 2 investigated narratives produced by adult native speakers of English, Spanish, Japanese, and Turkish, elicited with the aid of a picture storybook. The study was conducted to test whether the pattern of results found in Study 1 holds for other SVO and SOV languages besides English and Japanese. Spanish was chosen because it is an SVO pro-drop language, and Turkish because it is an SOV pro-drop language. Frog, where are you? (Mayer 1969) is a picture book that has a transparent story line (a boy looking for his frog), but no words. The book has been used to collect narratives in a number of languages from speakers belonging to various age groups, with a fair amount of the data available online (cf. Berman \& Slobin 1994). Since the data were gathered from narratives based on the same set of pictures, the content was expected to be controlled across speakers and languages. In addition, as the data included narratives produced by multiple speakers for each language, it was expected that we would find a reliably consistent pattern within a given language that would not be sensitive to individual speaker variation.

\section{$<\mathrm{B}>3.1$ Methods}

\section{$<\mathrm{C}>3.1 .1$ Materials}

A total of 1,211 sentences were analyzed. These sentences were narratives of the 'frog story' elicited from adult native speakers of English, Spanish, Japanese, and Turkish. The English data consisted of 10 speakers' frog stories (473 sentences in total), and the Japanese data consisted of 10 speakers' frog stories (275 sentences in total), both elicited by Seig (1999). The Spanish data consisted of five speakers' frog stories (198 sentences in total), and the Turkish data consisted of five speakers' frog stories (265 sentences in total), both taken from CHILDES.

\section{$<\mathrm{C}>3.1 .2$ Procedures}


The English and Japanese data were coded by the same Japanese graduate student in syntax who did the coding in Study 1. The Spanish data were coded by a Spanish graduate student in syntax at the University of Illinois, and the Turkish data were coded by the first author using a native speaker of Turkish as a language informant. Sentences were coded in the same way as in Study 1 (see section 2.1.2 above).

The number of sentence tokens of each predicate type ('two-place predicate', 'one-place predicate', 'sentence fragment', etc.) for each language was counted. In addition, the number of sentence tokens with null arguments for each predicate type was tallied for Spanish, Japanese, and Turkish. To test the Pro-drop bias, one-tailed paired t-tests were conducted on the percentage of pro-drop in one-place predicates vs. two-place predicates for the three pro-drop languages, in order to see whether any language would show a higher rate of pro-drop with two-place than with one-place predicates across speakers. To test the Intransitive bias, an analysis of variance was run to compare the proportion of one-place predicates between SVO and SOV languages, with 'VO $\sim \mathrm{OV}$ ' as the main factor and 'Language' as a nested factor (with English and Spanish nested within VO, and Japanese and Turkish nested within OV), so as to see whether SOV languages would have a higher percentage of one-place predicates than SVO languages. Furthermore, one-tailed grouped t-tests were conducted for pairwise $\mathrm{VO} \sim \mathrm{OV}$ comparisons between the languages of interest, namely, English vs. Japanese, English vs. Turkish, Spanish vs. Japanese, and Spanish vs. Turkish. As in Study 1, an alpha level of .05 was used for all statistical tests.

$<\mathrm{B}>3.2$ Results

$<\mathrm{C}>3.2 .1$ Pro-drop bias 
Figure 4 shows the mean proportion of pro-drop with one-place vs. two-place predicates for the three pro-drop languages, namely, Spanish, Japanese, and Turkish. As can be seen from the figure, every language shows a higher percentage of pro-drop with two-place predicates than with one-place predicates. This is statistically supported for all the languages [one-place vs. two place, Spanish: 38\% (standard deviation (SD) 11\%) vs. 67\% (SD 21\%), t(4) =-4.64, p <.01; Japanese: $12 \%$ (SD 8\%) vs. 33\% (SD 20\%), t(9) =-3.31, p <.01; Turkish: 31\% (SD 11\%) vs. $51 \%(\operatorname{SD} 5 \%), \mathrm{t}(4)=-3.31, \mathrm{p}<.05]$

\section{$<$ Figure 4 about here $>$}

Table 6 shows the mean number of sentences showing pro-drop for each category, speaker, and language. For all the languages, the majority of pro-drop is S-drop (Spanish 99\%, Japanese 69\%, Turkish 96\%). Other cases include O-drop only for Spanish (1\%) and Japanese $(24 \%)$ and SO-drop for Japanese (8\%) and Turkish $(4 \%){ }^{8}<\mathrm{FN} 8>$

\section{$<$ Table 6 about here $>$}

Table 7 shows the types of null subject arguments. For all the languages, animate third person references were dominant (Spanish 85\%, Japanese 87\%, Turkish 93\%) and referred to the characters in the frog story, such as the boy, his dog, and his frog. Most of the inanimate referents were situational 'it'.

\section{$<$ Table 7 about here $>$}

Table 8 shows the types of null object arguments. Almost all of the referents were animate third person - again, the characters of the frog story. Thus all of the referents appear to be previously mentioned in the story, and accordingly it seems more natural that they would have been pronouns/demonstratives rather than lexical NPs, had they been overtly expressed.

\section{$<$ Table 8 about here $>$}




\section{$<\mathrm{C}>3.2 .2$ Intransitive bias}

Figure 5 shows the mean proportion of one-place vs. two-place predicates for the four languages. As shown in the figure, the SOV languages (Japanese 64\% (SD 11\%), Turkish 56\% (SD 5\%)) exhibit a higher percentage of one-place predicates than the SVO languages (English 50\% (SD $9 \%$ ), Spanish 45\% (SD 5\%)). This observation is statistically supported by an overall analysis of variance comparing the proportion of one-place predicates between SVO (with English and Spanish nested) and SOV (with Japanese and Turkish nested) $[\mathrm{F}(1,26)=11.01, \mathrm{p}=.003]$. When each pair of SVO vs. SOV languages is compared individually, the Intransitive bias is also statistically supported for all the pairs [English vs. Japanese: $\mathrm{t}(18)=-2.95, \mathrm{p}<.01$; Spanish vs. Japanese: $\mathrm{t}(13)=-3.29, \mathrm{p}<.01 ;$ Spanish vs. Turkish $\mathrm{t}(8)=-2.81, \mathrm{p}<.05$ ], except for the pair of English and Turkish, which follows the trend numerically but does not show a statistically significant difference $[\mathrm{t}(13)=-1.21, \mathrm{p}=.124]$.

\section{$<$ Figure 5 about here $>$}

\section{$<\mathrm{B}>3.3$ Study 2: preliminary discussion}

Overall, the pattern of results found in Study 1 was generally replicated in Study 2 and was consistent with the Pro-drop and Intransitive bias hypotheses we have proposed. Every pro-drop language (Spanish, Japanese, and Turkish) showed significantly more instances of pro-drop with two-place predicates than with one-place predicates. Recall that the characteristics of null subjects were different between child English and Japanese in Study 1, in that first and second person referents were dominant in child English, while third person referents were dominant in Japanese. The characteristics of null objects, in contrast, were the same in both languages: the referents of almost all null objects were inanimate third person. In Study 2 a large majority of both null subjects and null objects had animate third person referents in all languages. This is 
probably due to the nature of the frog story in that it involves several animate characters, who would likely be referred to in the third person by the storyteller.

As expected from our Intransitive bias hypothesis, one-place predicates were generally predominant in the SOV languages (Japanese, Turkish), but not in the SVO languages (English, Spanish). When each of the SOV and SVO languages were compared pairwise, there were significantly more instances of one-place predicates in the relevant SOV language than in the SVO language, except for the English and Turkish pair, where this difference was not statistically significant. This may be because Turkish is less rigidly head-final than Japanese: in general, there seems to be a sharp divide in grammatical properties between rigid SOV languages (Japanese, Korean) and SOV languages that are more accommodating of post-verbal constituents, such as Turkish (see Kural 1997 on postverbal material in Turkish, and Dryer 2007 for a more general typological discussion of rigid and flexible SOV languages).

Study 2 showed definite individual variation across speakers as shown by the standard deviations for both the Pro-drop and Intransitive biases. However, when the data from individual speakers were averaged and submitted to statistical tests, they were consistent with our two hypotheses. Therefore, our conclusion for Study 2 is that both of our hypotheses continue to hold even when other languages besides English and Japanese, including SVO pro-drop (Spanish) and SOV pro-drop (Turkish) language, are used.

\section{$<\mathrm{A}>4$. GENERAL DISCUSSION}

In summary, Study 1 has shown that English and Japanese speakers seem to utilize strategies to facilitate processing by minimizing the number of overt arguments with pro-drop (for both child English and all genres of Japanese) and also by minimizing structural constraints by using oneplace predicates (for Japanese). Study 2 shows the same thing for pro-drop languages to facilitate 
processing by using pro-drop (Spanish, Japanese, Turkish) and one-place predicates (Japanese and to some extent Turkish). In what follows, we will discuss each of these findings in relation to our proposed biases/hypotheses.

\section{$<\mathrm{B}>4.1$ Pro-drop bias}

As predicted by the Pro-drop bias hypothesis, our data show that pro-drop is more prevalent with two-place predicates than with one-place predicates in pro-drop languages (Spanish, Japanese, and Turkish), as well as in child English. As mentioned in the Introduction, this hypothesis holds true for other languages and genres as well. If we apply the same statistical analyses to other published data, we find the same pattern of results (see table 9). A corpus of spoken Spanish (SVO with rich verb agreement) by Bentivoglio (1992) shows a significantly higher percentage of pro-drop with two-place predicates than with one-place predicates [one-place vs. two place: $458(67 \%)$ vs. $\left.331(76 \%), \chi^{2}(1)=11.73, \mathrm{p}<.001\right],{ }^{9}<$ FN9 $>$ just as our Study 2 does. Similarly, a corpus of spoken Mandarin (SVO with no verb agreement) by Tao (1996) also shows a significantly higher percentage of pro-drop with two-place predicates than with one-place predicates ${ }^{10}<\mathrm{FN} 10>$ [one-place vs. two place: $130(40 \%)$ vs. $232(81 \%), \chi^{2}(1)=106.53, \mathrm{p}$ $<.001]$. In addition, Sacapultec Maya, an ergative verb-object-subject (VOS) language with rich verb agreement, also shows a Pro-drop bias; according to a spoken corpus by Du Bois (1987), there is a significantly higher percentage of pro-drop with two-place predicates than with oneplace predicates [one-place vs. two place: $124(47 \%)$ vs. $156(87 \%), \chi^{2}(1)=71.11, p$ $<.001] .{ }^{11}<$ FN11 $>$ Our own data showed that SOV languages, such as Japanese (no agreement) and Turkish (rich agreement), in addition to child English (SVO with some agreement), also have the same bias. There thus seems to be a general trend across languages of various basic 
word orders and agreement systems towards shortening two-place predicate utterances by means of pro-drop.

\section{$<$ Table 9 about here $>$}

There may, therefore, be a general principle of economy in processing that applies to languages of all word order types, in that it is easier both to comprehend and to produce fewer arguments. In terms of comprehension, pro-drop with a two-place predicate reduces the number of overt NPs that must be processed, whether before or after the verb. Assuming again that recovering null pronouns is not costly, it would be more economical to comprehend shorter constructions with pro-drop than longer constructions with overt NPs. In terms of production, shorter utterances would also be easier to produce. As mentioned earlier, P. Bloom (1990) reports that VP length in English-speaking children's utterances increases as a function of the subject type. If we recast 'shorter utterances' as 'fewer overt arguments', our data are consistent with Bloom's claim for all the genres in Japanese, for children's utterances in English in Study 1, for the adult narratives in all the pro-drop languages (Spanish, Japanese, and Turkish) in Study 2, as well as for the adults' spoken corpora in Spanish (Bentivoglio 1992), Mandarin (Tao 1996), and Sacapultec Maya (Du Bois 1987) discussed above. Therefore, as hypothesized in the Introduction, although adults are not subject to performance restrictions to the same extent that children are, they still seem to prefer to shorten their utterances. This is consistent with the view that pro-drop serves to satisfy performance constraints, at least to a certain degree, as opposed to the view that pro-drop is fundamentally a competence-based phenomenon (e.g. Hyams \& Wexler 1993).

It should be noted, however, that easing of processing load may not be the only motivation for shortening utterances - there may be an interaction with discourse factors. Recall 
from table 1 in Study 1 and table 6 in Study 2 that subject NPs are much more likely to be dropped than object NPs in all of the languages we examined. ${ }^{12}<$ FN12> This is consistent with data reported in earlier work concerning children's utterances in English and Japanese (Mazuka et al. 1986 for Japanese, P. Bloom 1990 and Hyams \& Wexler 1993 for English). ${ }^{13}<$ FN13> This dominance of S-drop could certainly be explained in terms of processing load. If we follow Yngve (1960) as discussed in the Introduction, the most costly argument is the leftmost argument, which is an S. Thus S-drop would reduce the production cost more than O-drop would, for both SVO and SOV languages. However, it is also possible to offer a discourse account for the S-drop preferences. P. Bloom $(1990,1993)$ argues that the tendency to drop subject NPs more than object NPs may be due to pragmatic factors surrounding subjects, which tend to be more 'given' than objects, and thus more prone to being omitted at a processing bottleneck. If subjects typically convey 'given' information (that is, previously mentioned and already activated, e.g. Chafe 1976), while objects convey 'new' (newly introduced) information, it is not surprising that subjects tend to be omitted more than objects. Similarly, Du Bois (1987) discusses how discourse factors explain why O-drop occurs less frequently and why two-place predicates tend to have more pro-drop than one-place predicates. Du Bois argues that there tends to be only one lexical argument (which contributes new information) in a clause in Sacapultec Maya, probably because introducing a new lexical argument referent makes sufficient demands on one's attention that simultaneous introduction of a second new referent within the same clause would be too costly. The lexical argument appears preferentially in the S (intransitive subject) or O (transitive object) roles, but rarely in the A (transitive subject) role. This is because human agents (which occupy the A role) tend to be the topic and 'given' information in the sentence, while objects tend to be 
'new' information, and intransitive clauses tend to be used when new human referents are introduced. As a result, the A role tends to be reduced to an overt or silent pronoun.

At any rate, although we cannot be completely sure how much of the Pro-drop bias is due to performance constraints on comprehending and producing sentences and how much is due to discourse factors, we can certainly say that performance and discourse interact with each other. Whether it is written or spoken, language in general seems to be under some pressure to make room for information having a greater need of being expressed (e.g. new information) by reducing information with a lesser need of being expressed (e.g. given, easily recoverable information). And this 'pressure' may well inhere in a processing constraint whose effect is to make utterances shorter for ease of comprehension and production. Furthermore, although it may seem that dropping both subject and object (SO-drop in tables 1 and 6) would shorten an utterance even further and thus make it still easier to process, there would be a tension between being short and being clear. Omitting both subject and object would tend to make the content of a given sentence unclear, and that is probably why there are very few instances of SO-drop. Therefore, it would be better to keep a less salient argument overt and only omit a more salient argument (which tends to be the subject).

\section{$<\mathrm{B}>4.2$ Intransitive bias}

As predicted by our Intransitive bias hypothesis, our results show that the SOV languages we have investigated (Japanese, Turkish) generally exhibit a higher proportion of one-place predicates to two-place predicates than the SVO languages we have looked at (English, Spanish). In terms of comprehension, the greater preference for one-place predicates shown by verb-final languages can be understood quite naturally as a processing strategy designed to reduce the number of arguments that need to be held in working memory until the verb is encountered, as 
discussed in the Introduction. Therefore, despite the skepticism regarding Pritchett's head-driven parser model (recall section 1.1, and cf. Kamide \& Mitchell 1999, Kamide et al. 2003, Aoshima et al. 2004), having a verb appear later rather than sooner may still call forth a compensatory strategy. In terms of production, reducing the number of arguments before the verb can minimize the 'depth' in the phrase structure (Yngve 1960) and the time to get to the verb (Lindsley 1975). It is possible that SOV is POTENTIALLY harder to process, ${ }^{14}<\mathrm{FN} 14>$ both in terms of comprehension and production, which would motivate the preferential use of one-place predicates to reduce the number of preverbal arguments. Furthermore, this compensatory strategy seems to allow for an equally easy processing of languages with different basic word orders.

In addition to our frequency data, there is additional evidence from language acquisition that suggests that Japanese has a preference for one-place over two-place predicates, and thus an Intransitive bias. Rispoli (1987), Nomura \& Shirai (1997), Fukuda \& Choi (2009), and Tsujimura (2006) show that Japanese children under 3;0 use intransitive verbs significantly more often than transitive verbs - in contrast to their Portuguese or English-speaking peers. Fukuda \& Choi (2009) also report a developmental advantage for intransitives in Japanese: Japanesespeaking children start using the intransitive versions of verbs that have transitive counterparts (e.g. $a k u$ 'open(int.)' vs. $a k-e-r u$ 'open(tr.)') two to three months earlier than the transitive versions. By contrast, an English-speaking child starts producing transitive versions approximately six months earlier than their intransitive counterparts. We presume that the Intransitive bias mirrors the pattern of acquisition in child language (see Kidd et al. 2007 for the close relationship between the comprehension and production systems of children and adults). Furthermore, the Intransitive bias hypothesis is also consistent with the observation in Nichols, 
Peterson \& Barnes (2004) that there may be cross-linguistic variation in the preference for onevs. two-place predicates. To describe this difference in adicity, Nichols et al. propose the notion of lexical valence orientation. This notion captures the descriptive generalization that some languages are predominantly intransitive and morphologically derive transitive verbs from intransitive forms, while other languages are predominantly transitive, deriving one-place predicates via detransitivization. ${ }^{15}<$ FN15> In examining correlations between various language properties and lexical valence orientation, Nichols et al. (2004: 170) note that languages of the SOV type (which they refer to as OV languages) favor the intransitive orientation; they suggest that this correlation is grammatically driven (as opposed to being an areal feature) but do not provide an explanation for it. If the results obtained for Japanese (and Turkish) are reliably replicated in other head-final languages, the correlation noted by Nichols and colleagues receives a processing explanation: the predominance of one-place verbs in OV languages is consistent with the hypothesis that the number of arguments before the verb needs to be kept small.

\section{$<\mathrm{B}>4.3$ Conclusion}

We started out with the general question of whether or not differences in basic word order correlate with principled differences in processing. This question was inspired by earlier work on the differences between SOV and SVO languages in terms of constituent placement, such as the long-before-short principle demonstrated for an SOV language by Yamashita \& Chang (2001).

Our own results point toward a heretofore unknown way in which SOV and SVO languages differ. The main difference uncovered here has to do with the proportion of one-place to two-place predicates. We found that SOV languages show an Intransitive bias: they use a higher proportion of one-place verbs. This bias is further supported by acquisition data (at least 
for Japanese), which indicate that child learners start out with a higher number of one-place predicates and develop them earlier.

The generalization that SOV languages show an Intransitive bias is quite robust. It is consistent with data from Japanese and Turkish, and, more indirectly, with the data on head-final languages in Nichols et al. (2004). The explanation for this generalization (which of course needs to be tested in more head-final languages) is more tentative, but we would like to venture that it is related to processing. The main idea is that an SOV structure with all the constituents expressed is potentially harder to process, possibly in terms of both comprehension and production. In this context, the dominance of one-place predicates works as a compensatory strategy to reduce the number of preverbal arguments.

However, the number of preverbal arguments can be reduced by several means; for example, arguments that are recoverable from the context or from agreement could simply be omitted. This is of course the well-known pattern of pro-drop, which could potentially ease the processing bottleneck before the final predicate. Thus, one might suppose that pro-drop would be more prevalent in two-argument structures and that such a bias (the Pro-drop bias, in our terminology) would be more pronounced in SOV languages. This expectation is not met. Our corpus study showed that the occurrence of pro-drop was uniformly higher in two-argument structures, regardless of the OV/VO distinction. This finding has two implications. First, the Prodrop bias seems to emerge as a universal economy principle for making utterances shorter, possibly interacting with discourse factors. As such, this principle does not show sensitivity to headedness, but is clearly sensitive to the number of arguments. Second, the observation that the Pro-drop bias is not sufficient to ameliorate the processing difficulty in SOV sentences suggests that processing is simultaneously subject to surface factors (weight, number of overt 
constituents) and to structural factors, such as valency. This in turn offers support for the general idea that there is an intimate interaction between grammar and parser, which has been advanced by a number of researchers (Phillips 1996, 2003, 2006; O’Grady 1997, 2005).

The tendencies we have presented here are quite robust and are supported by various statistics. It remains to be seen if further studies of other SOV/SVO languages will be consistent with our conclusions. If our generalizations are on the right track, they may provide a new tool that will be useful in determining the basic word order for languages where the surface facts are far from clear: presumably, head-final languages will tend to show the Intransitive bias we have uncovered here, while all types of languages will show the Pro-drop bias. Thus, our data suggest that human languages utilize both word-order-specific and universal strategies to facilitate processing. The Intransitive bias is specific to head-final languages, whereas the Pro-drop bias emerges as a more general strategy.

$<$ Heading in caps \& centered; please follow copy layout/formatting in the list in this section $>$

\section{DATA SOURCE REFERENCES}

\section{STUDY 1}

1. Home decoration magazines

House Beautiful, May 1998, 80-81.

Home Remodeling \& Decoration, Winter 1997-98, 25-34.

Nachuraru-na Interia (Natural Interior), May 1998, 30-37.

2. Mystery novels

Stephen King. 1999. The girl who loved Tom Gordon, 3-30. New York: Pocket Books.

Mariko Koike. 1997. Kikenna shokutaku [The dangerous dinner table], 10-26. Tokyo:

Shueisha. 
3. Books about Japanese politics

Bradley M. Richardson \& Scott C. Flanagan. 1984. Politics in Japan, 117-139. Boston, MA: Little, Brown and Company.

Juichi Aiba, Tadashi Iyasu \& Shoji Takashima. 1998. Nihon seiji-o yomu [Reading Japanese politics], 1-42. Tokyo: Kodansha.

4. Children's utterances: CHILDES

STUDY 2

1. English

Mary Theresa DiGennaro Seig. 1999. A crosslinguistic comparison: Episodic boundaries in Japanese and English narratives. Ph.D. dissertation, Oklahoma State University.

2. Spanish: CHILDES

3. Japanese

Mary Theresa DiGennaro Seig. 1999. A crosslinguistic comparison: Episodic boundaries in Japanese and English narratives. Ph.D. dissertation, Oklahoma State University.

4. Turkish: CHILDES

\section{$<$ Refs $>$ REFERENCES}

Aoshima, Sachiko, Colin Phillips \& Amy Weinberg. 2004. Processing of filler-gap dependencies in a head-final language. Journal of Memory and Language 51, 23-54.

Bentivoglio, Paola. 1992. Linguistic correlations between subjects of one-argument verbs and subjects of more-than-one-argument verbs in spoken Spanish. In Paul Hirschbühler \& Konrad Koerner (eds.), Romance languages and modern linguistic theory: 20th Linguistic Symposium on Romance Languages (LSRL XX), Ottawa, 10-14 April 1990, 11-24. Amsterdam: John Benjamins. 
Berman, Ruth A. \& Dan I. Slobin. 1994. Relating events in narrative: A crosslinguistic developmental study. Hillsdale, NJ: Lawrence Erlbaum.

Bloom, Lois. 1970. Language development: Form and function in emerging grammars. Cambridge, MA: MIT Press.

Bloom, Paul. 1990. Subjectless sentences in child language. Linguistic Inquiry 21, 491-504.

Bloom, Paul. 1993. Grammatical continuity in language development: The case of subjectless sentences. Linguistic Inquiry 24, 721-734.

Braine, Martin D. S. 1976. Children's first word combinations (Monographs of the Society for Research in Child Development 41). Chicago: University of Chicago Press.

Chafe, Wallace L. 1976. Givenness, contrastiveness, definiteness, subjects, topics and point of view. In Charles N. Li (ed.), Subject and topic, 25-56. New York: Academic Press.

Comrie, Bernard. 1993. Language universals and linguistic typology: Data-bases and explanations. Sprachtypologie und Universalienforschung 46, 3-14.

Comrie, Bernard. 2008. Alignment of case marking. In Haspelmath et al. (eds.), chapter 98.

Dryer, Matthew S. 2007. Word order. In Timothy Shopen (ed.), Clause structure, language typology and syntactic description, 2nd edn., vol. 1, 61-131. Cambridge: Cambridge University Press.

Dryer, Matthew S. 2008. Order of subject, object, and verb. In Haspelmath et al. (eds.), chapter 81.

Dubinsky, Stanley. 1993. Case-motivated movement to non-argument positions: Evidence from Japanese. In Patricia M. Clancy (ed.), Japanese/Korean Linguistics 2, 338-354. Stanford, CA: CSLI Publications. 
Du Bois, John W. 1987. The discourse basis of ergativity. Language 63, 805-855.

Ferreira, Victor S. \& Gary S. Dell. 2000. The effect of ambiguity and lexical availability on syntactic and lexical production. Cognitive Psychology 40, 296-340.

Fukuda, Shin \& Soonja Choi. 2009. The acquisition of transitivity in Japanese and Korean children. Shoichi Iwasaki, Hajime Hoji, Patricia M. Clancy \& Sung-Ock Sohn (eds.), Japanese/Korean Linguistics 17, n-m. Stanford, CA: CSLI Publications.

Garnsey, Susan M., Neal J. Pearlmutter, Elizabeth Myers \& Melanie A. Lotocky. 1997. The contributions of verb bias and plausibility to the comprehension of temporarily ambiguous sentences. Journal of Memory and Language 37, 58-93.

Gibson, Edward \& Gregory Hickok. 1993. Sentence processing with empty categories. Language and Cognitive Processes 8, 147-161.

Gilligan, Gary. 1987. A cross-linguistic approach to the pro-drop parameter. Ph.D. dissertation, University of Southern California.

Gorrell, Paul. 1993. Evaluating the direct association hypothesis: A reply to Pickering and Barry (1991). Language and Cognitive Processes 8, 129-146.

Greenberg, Joseph H. 1966. Universals of language, 2nd edn. Cambridge, MA: MIT Press.

Haegeman, Liliane. 1990. Understood subjects in English diaries: On the relevance of theoretical syntax for the study of register variation. Multilingua 9, 157-199.

Haspelmath, Martin, Matthew S. Dryer, David Gil \& Bernard Comrie (eds.). 2008. The world atlas of language structures online. Munich: Max Planck Digital Library. Available at http://wals.info/feature (accessed on 2 April 2009).

Hawkins, John A. 1994. A performance theory of order and constituency. Cambridge: Cambridge University Press. 
Hawkins, John A. 1999. Processing complexity and filler-gap dependencies across grammars. Language 75, 244-285.

Hawkins, John A. 2002. Symmetries and asymmetries: Their grammar, typology and parsing. Theoretical Linguistics 28, 95-149.

Hawkins, John A. 2004. Efficiency and complexity in grammars. Oxford: Oxford University Press.

Haywood, Sarah L., Martin J. Pickering \& Holly P. Branigan. 2005. Do speakers avoid ambiguities during dialogue? Psychological Science 16, 362-366.

Hewitt, George. 1979. Abkhaz (Lingua Descriptive Studies 2). Amsterdam: North-Holland. Hyams, Nina \& Kenneth Wexler. 1993. On the grammatical basis of null subjects in child language. Linguistic Inquiry 24, 421-459.

Kameyama, Megumi. 1985. Zero anaphora: The case of Japanese. Ph.D. dissertation, Stanford University.

Kameyama, Megumi. 1988. Japanese zero pronominal binding: Where syntax and discourse meet. In William J. Poser (ed.), 2nd International Workshop on Japanese Syntax, 47-73. Stanford, CA: CSLI Publications.

Kamide, Yuki, Gerry T. M. Altmann \& Sarah L. Haywood. 2003. The time-course of prediction in incremental sentence processing: Evidence from anticipatory eye movements. Journal of Memory and Language 49, 133-156.

Kamide, Yuki \& Don C. Mitchell. 1999. Incremental pre-head attachment in Japanese parsing. Language and Cognitive Processes 14, 631-662.

Kayne, Richard S. 1994. The antisymmetry of syntax (Linguistic Inquiry Monograph 25). Cambridge, MA: MIT Press. 
Kidd, Evan, Silke Brandt, Elena Lieven \& Michael Tomasello. 2007. Object relatives made easy: A cross-linguistic comparison of constraints influencing young children's processing of relative clauses. Language and Cognitive Processes 22, 860-897.

Kuno, Susumu. 1973. The structure of the Japanese language. Cambridge, MA: MIT Press.

Kuno, Susumu \& Yuki Johnson. 2005. On the non-canonical double nominative constructions in Japanese. Studies in Language 29, 285-328.

Kural, Murat. 1997. Postverbal constituents in Turkish and the Linear Correspondence Axiom. Linguistic Inquiry 28, 498-519.

Lindsley, James R. 1975. Producing simple utterances: How far ahead do we plan? Cognitive Psychology 7, 1-19.

Mayer, Mercer. 1969. Frog, where are you? New York: Dial.

Mazuka, Reiko, Barbara Lust, Tatsuko Wakayama \& Wendy Snyder. 1986. Distinguishing effects of parameters in early syntax acquisition: A cross-linguistic study of Japanese and English. Papers and Reports on Child Language Development 25, 73-82.

Moro, Andrea. 2000. Dynamic antisymmetry (Linguistic Inquiry Monograph 38). Cambridge, MA: MIT Press.

Nichols, Johanna, David A. Peterson \& Jonathan Barnes. 2004. Transitivizing and detransitivizing languages. Linguistic Typology 8, 149-211.

Nomura, Matsuko \& Yasuhiro Shirai. 1997. Overextension of intransitive verbs in the acquisition of Japanese. In Eve V. Clark (ed.), 28th Annual Child Language Research Forum, 233-242. Stanford, CA: CSLI Publications.

O’Grady, William. 1997. Syntactic development. Chicago: University of Chicago Press. 
O’Grady, William. 2005. Syntactic carpentry: An emergentist approach to syntax. Mahwah, NJ: Lawrence Erlbaum.

Phillips, Colin. 1996. Order and structure. Ph.D. dissertation, MIT.

Phillips, Colin. 2003. Linear order and constituency. Linguistic Inquiry 34, 37-90.

Phillips, Colin. 2006. The real-time status of island phenomena. Language 82, 795-823.

Pickering, Martin [J.]. 1993. Direct association and sentence processing: A reply to Gorrell and to Gibson and Hickok. Language and Cognitive Processes 8, 163-196.

Pickering, Martin [J.] \& Guy Barry. 1991. Sentence processing without empty categories. Language and Cognitive Processes 6, 229-259.

Prince, Ellen. 1999. Subject pro-drop in Yiddish. In Peter Bosch \& Rob van der Sandt (eds.), Focus: Linguistic, cognitive, and computational perspectives, 82-104. Cambridge: Cambridge University Press.

Pritchett, Bradley. 1992. Grammatical competence and parsing performance. Chicago: University of Chicago Press.

Rispoli, Matthew. 1987. The acquisition of verbs in Japanese. First Language 7, 183-200.

Rizzi, Luigi. 1994. Root null subjects and early null subjects. In Teun Hoekstra \& Bonnie Schwartz (eds.), Language acquisition studies in generative grammar, 151-176. Amsterdam: John Benjamins.

Seig, Mary Theresa DiGennaro. 1999. A crosslinguistic comparison: Episodic boundaries in Japanese and English narratives. Ph.D. dissertation, Oklahoma State University.

Shibatani, Masayoshi. 1976. Grammatical relations and surface cases. Language 53, 789-809. Shibatani, Masayoshi. 1990. The languages of Japan. Cambridge: Cambridge University Press. 
Siewerska, Anna. 1996. Word order type and alignment type. Sprachtypologie und Universalienforschung 49, 149-176.

Svartvik, Jan. 1966. On voice in the English verb. The Hague: Mouton.

Takezawa, Koichi. 1987. The dative-marked subject and the nominative-marked object in Japanese: Configurational evidence. University of Washington Working Papers in Linguistics 9, 37-50.

Tao, Hongyin. 1996. Units in Mandarin conversation: Prosody, discourse, and grammar. Philadelphia, PA: John Benjamins.

Trueswell, John C., Michael K. Tanenhaus \& Christopher Kello. 1993. Verb-specific constraints in sentence processing: Separating effects of lexical preference from garden-paths. Journal of Experimental Psychology: Learning, Memory, and Cognition 19, 528-553.

Tsujimura, Natsuko. 2006. Why not all verbs are learned equally: The intransitive verb bias in Japanese. In Natalia Gagarina \& Insa Gülzow (eds.), The acquisition of verbs and their grammar: The effect of particular languages, 105-124. Berlin: Springer.

Turan, Ümit Deniz. 1998. Ranking forward-looking centers in Turkish: Universal and languagespecific properties. In Marilyn A. Walker, Aravind K. Joshi \& Ellen F. Prince (eds.), Centering theory in discourse, 139-161. Oxford: Clarendon Press.

Walker, Marilyn A., Masayo Iida \& Sharon Cote. 1994. Japanese discourse and the process of centering. Computational Linguistics 20, 193-231.

Wasow, Thomas. 1997. Remarks on grammatical weight. Language Variation and Change 9, $81-105$.

Yamashita, Hiroko \& Franklin Chang. 2001. 'Long before short' preference in the production of a head-final language. Cognition 81, B45-B55. 
Yamashita, Hiroko, Franklin Chang \& Yuki Hirose. 2005. Producers build structures only with overt arguments. Presented at the Eighteenth Annual CUNY Conference on Human Sentence Processing, The University of Arizona, Tucson.

Yngve, Victor H. 1960. A model and an hypothesis for language structure. The American Philosophical Society 104, 444-466.

\author{
$<$ ADDRESSES $>$ \\ Authors' addresses: (Ueno) \\ Department of Linguistics, 0108, University of California, San Diego, \\ La Jolla, CA 92093-0108, USA \\ ueno@ling.ucsd.edu \\ (Polinsky) \\ Department of Linguistics, Harvard University, \\ Cambridge, MA 02138, USA \\ polinsky@fas.harvard.edu \\ $<$ Leave blank $>$
}




\section{$<$ FOOTNOTES $>$}

${ }^{1}$ This work was supported by an NIMH postdoctoral training fellowship (T32 MH19554) at the University of Illinois and a Faculty Research Award at the University of Oregon to the first author and an award from the Harvard FAS Fund to the second author. We would like to thank Kay Bock, Bernard Comrie, Wind Cowles, Jeanette Gundel, Robert Kluender, Andrew Nevins, Johanna Nichols, and two anonymous $J L$ reviewers for helpful suggestions, and Orin Gensler and Ewa Jaworska for the the insightful comments on the prefinal version of this paper. We are grateful to Shin Fukuda, Alper Mizrak, Anita Saalfeld, and Marisol Garrido for help with data coding, and Mary Theresa Seig for providing us with her 'frog story' data in English and Japanese. All errors are our sole responsibility.

${ }^{2}$ We thank Kay Bock for pointing this out.

${ }^{3}$ The only exception is that the type coding of null subject and object arguments (tables 2-3) was done by the first author.

${ }^{4}$ As an operational procedure, an NP is considered not to be an object if it cannot appear as a passive subject. Based on this, the nominative-marked NPs in these constructions were coded as subjects. However, we also paid attention to lines of analysis which propose that certain stative verbals like these constructions are actually transitive, and their second ga-marked argument is a nominative-marked object (Kuno 1973; Shibatani 1976, 1990; Kuno \& Johnson 2005).

${ }^{5}$ Other pro-drop languages (Spanish and Turkish) will be considered in Study 2.

${ }^{6}$ As P. Bloom (1990) notes, it is not clear whether children's intuition about which verbs take obligatory objects would be identical to the adults', but we assume it is. 
${ }^{7}$ A reviewer points out that if all argument NPs had an equal chance to be dropped, we should expect greater pro-drop with two-place predicates just because they have twice as many arguments as one-place predicates. However, as seen in table 1, the overwhelming majority of instances of pro-drop involve S-drop or SO-drop (child English 62\%, Japanese 98\%). Therefore, it is not the case that subjects and objects are equally easy to drop and hence that two-place predicates should be twice as likely to drop an argument. The pattern of results stays the same even if we exclude O-drop and consider only S-drop or SO-drop to count as pro-drop (in this way, one-place and two-place predicates would have an equal chance for pro-drop per predicate) and run chi-square tests, in that there is a significantly higher percentage of pro-drop with twoplace predicates than with one-place predicates for child English [one-place vs. two place: 3\% vs. $11 \%, \chi^{2}(1)=4.94, p<.05$ ], for all the genres collapsed in Japanese [one-place vs. two place: $21 \%$ vs. $\left.36 \%, \chi^{2}(1)=23.40, p<.001\right]$, and for each for all the individual genre in Japanese [oneplace vs. two place, home decoration: $21 \%$ vs. $45 \%, \chi^{2}(1)=14.16, p<.001$; politics: $6 \%$ vs. $26 \%, \chi^{2}(1)=24.37, p<.001 ;$ children: $49 \%$ vs. $\left.77 \%, \chi^{2}(1)=9.48, p<.01\right]$ except for mystery novels, which follow the trend numerically but whose difference is not statistically significant [one-place vs. two place: $21 \%$ vs. $\left.24 \%, \chi^{2}(1)=0.18, p=.676\right]$.

${ }^{8}$ The overwhelming majority (Spanish 99\%, Japanese 76\%, Turkish 100\%) of instances of pro-drop in Study 2 involve S-drop or SO-drop (see table 6, and cf. footnote 7 for the same result in Study 1). Therefore, it is again not the case that subjects and objects are equally easy to drop and that two-place predicates should hence be twice as likely to omit an argument. The pattern of results stays basically the same even if we exclude O-drop and treat only S-drop or SO-drop as pro-drop (in this way, one-place and two-place predicates would have an equal chance for pro-drop per predicate) and run t-tests, in that there is a significantly higher 
percentage of pro-drop with two-place predicates than with one-place predicates for Spanish [one-place vs. two place: $38 \%$ (SD 11\%) vs. $66 \%(\mathrm{SD} 21 \%), \mathrm{t}(4)=-4.45, \mathrm{p}<.01]$ and Turkish [one-place vs. two place: $31 \%$ (SD 11\%) vs. $51 \%$ (SD 5\%), t(4) $=-3.31, \mathrm{p}<.05$ ]. Although in Japanese the difference is not statistically significant, Japanese does follow the trend numerically [one-place vs. two place: $12 \%$ (SD 8\%) vs. $19 \%(\mathrm{SD} 18 \%), \mathrm{t}(9)=-1.27, \mathrm{p}=.118]$.

${ }^{9}$ This is based on a conservative calculation using only the overt and covert pronouns in 'Table 2a: Distribution of S and A subjects according to form (Ø, P, N)' in Bentivoglio (1992: 16). We did not include lexical NPs in our calculation at all as they can be mere presentational NPs, such as 'Here comes the bride', instead of real subjects. As there are more (overt) NPs in intransitive than transitive constructions, adding non-presentational NPs is likely to further magnify the Pro-drop bias in the data.

${ }^{10}$ Note that 'one-place predicates' here includes only intransitives and statives and does not include copular constructions (Tao 1996: 116-117).

${ }^{11}$ The calculation here is again conservative, in that it is based only on S-drop and SOdrop. There may be cases of O-drop only, but we have no way of knowing the number of such cases from Du Bois' (1987: 822) data.

${ }^{12}$ English-speaking children's utterances in Study 1 show the highest percentage (38\%) of object-drop (see table 1). This, however, is still lower than children's subject-drop (62\%), and the high figure is surely due to counting seven instances of I don't know, one instance of She wants to, and one instance of I want to as object-drop. If we do not count these as object-drop, the object-drop rate is only $10 \%$, but the pro-drop bias still holds [one-place vs. two place: $3 \%$ vs. $\left.12 \%, \chi^{2}(1)=6.31, p=.012\right]$. 
${ }^{13}$ In addition to these token frequency data, a cross-linguistic survey of pro-drop (Gilligan 1987) shows that object pro-drop is globally more restricted; among the 100 languages that roughly proportionally represent the language families of the world, $89 \%$ allow subject-drop, while $73 \%$ allow direct object-drop and only $26 \%$ permit indirect object-drop.

${ }^{14}$ If SOV is potentially harder to process, one may wonder why SOV is the most frequent basic word order in the world. As shown in table i below, $40 \%$ of the world's languages are SOV, while $35 \%$ are SVO (Dryer 2008).

$<$ Follow copy table + caption $>$

\begin{tabular}{crc}
\hline Word order & Count & Percentage \\
\hline SOV & 497 & $40 \%$ \\
SVO & 435 & $35 \%$ \\
VSO & 85 & $7 \%$ \\
VOS & 26 & $2 \%$ \\
OVS & 9 & $1 \%$ \\
OSV & 4 & $0 \%$ \\
None & 172 & $14 \%$ \\
Total & 1,228 & $100 \%$ \\
\hline
\end{tabular}

\section{Table $i$}

Basic word order in the world's languages (from Dryer 2008).

Although we do not have a definitive answer, we would like to offer several considerations. First, the difference between 40 and 35 per cent may not be too significant. Even if it were, the actual distribution of languages in the world may be due to a number of factors, many of which are non-linguistic: historical accidents, demographics, social and economic conditions (see Comrie 1993 for an insightful discussion). Next, as our results show, it is important to distinguish between rigid SOV languages and more flexible SOV languages - this distinction is masked in the counts shown in table i. If a language has both SOV and SVO order, 
it may not be immediately apparent what word order is preferred. And finally, ease of processing is not the only factor in the architecture of language - one needs to consider other factors, such as the adjacency of phrasal heads, or universal principles of linearization. With respect to the latter, compare the idea that all languages have a universal specifier-head-complement order, thus SVO, and that all other orders are derived from it (Kayne 1994, Moro 2000).

${ }^{15}$ Nichols et al. (2004) establish this generalization on the basis of overt morphological marking. The authors also recognize a third type, languages that seem to derive both types from a single stem using different morphology. This type is irrelevant to the points made in this paper. 


\section{$<5$ Figure captions; please follow copy line breaks in Fig. 4 \& 5 captions. $>$}

Figure 1

Pro-drop for one-place vs. two-place predicates in child English.

Figure 2

Pro-drop for one-place vs. two-place predicates in Japanese.

Figure 3

One-place vs. two-place predicates for English and Japanese.

Figure 4

Mean proportion of pro-drop for one-place vs. two-place predicates in Spanish, Japanese, and Turkish (averaged across speakers).

\section{Figure 5}

Mean proportion of one-place vs. two-place predicates for the 'frog story' in English, Spanish, Japanese, and Turkish (averaged across speakers).

$<9$ tables; for clarity, it may be necessary to follow copy vertical and horizontal lines; please follow copy line breaks in table captions.>

\begin{tabular}{|l|c||c|c|c|c|c|}
\hline & \multicolumn{1}{|c||}{ English } & \multicolumn{5}{c|}{ Japanese } \\
\cline { 2 - 7 } & \multirow{2}{*}{ Children } & $\begin{array}{c}\text { Home } \\
\text { decoration }\end{array}$ & Mystery & Politics & Children & Total \\
\hline \multirow{2}{*}{ S-drop only } & $\begin{array}{c}18 \\
(62 \%)\end{array}$ & $\begin{array}{c}70 \\
(88 \%)\end{array}$ & $\begin{array}{c}62 \\
(94 \%)\end{array}$ & $\begin{array}{c}34 \\
(100 \%)\end{array}$ & $\begin{array}{c}76 \\
(84 \%)\end{array}$ & $\begin{array}{c}242 \\
(90 \%)\end{array}$ \\
\hline \multirow{2}{*}{ SO-drop } & 0 & 6 & 2 & 0 & 13 & 21 \\
& $(0 \%)$ & $(8 \%)$ & $(3 \%)$ & $(0 \%)$ & $(14 \%)$ & $(8 \%)$ \\
\hline \multirow{2}{*}{ O-drop only } & 11 & 4 & 2 & 0 & 1 & 7 \\
& $(38 \%)$ & $(5 \%)$ & $(3 \%)$ & $(0 \%)$ & $(1 \%)$ & $(3 \%)$ \\
\hline \multirow{2}{*}{ Total } & 29 & 80 & 66 & 34 & 90 & 270 \\
& $(100 \%)$ & $(100 \%)$ & $(100 \%)$ & $(100 \%)$ & $(100 \%)$ & $(100 \%)$ \\
\hline
\end{tabular}

Table 1

Details of pro-drop types in English and Japanese. 


\begin{tabular}{|l|c|c|c|c|c|c|}
\hline \multirow{2}{*}{} & \multicolumn{1}{|c||}{ English } & \multicolumn{5}{c|}{ Japanese } \\
\cline { 2 - 6 } & Children & $\begin{array}{c}\text { Home } \\
\text { decoration }\end{array}$ & Mystery & Politics & Children & Total \\
\hline \multirow{2}{*}{1 st } & 4 & 10 & 26 & 10 & 5 & 51 \\
& $(22 \%)$ & $(13 \%)$ & $(41 \%)$ & $(29 \%)$ & $(6 \%)$ & $(19 \%)$ \\
\hline \multirow{2}{*}{ 2nd } & 6 & 10 & 7 & 0 & 9 & 26 \\
& $(33 \%)$ & $(13 \%)$ & $(11 \%)$ & $(0 \%)$ & $(10 \%)$ & $(10 \%)$ \\
\hline \multirow{2}{*}{ 3rd (animate) } & 8 & 2 & 19 & 8 & 7 & 36 \\
\multirow{2}{*}{3 rd (inanimate) } & $(44 \%)$ & $(3 \%)$ & $(31 \%)$ & $(24 \%)$ & $(8 \%)$ & $(14 \%)$ \\
\hline \multirow{2}{*}{ Total } & 0 & 54 & 12 & 16 & 68 & 150 \\
& $(0 \%)$ & $(71 \%)$ & $(19 \%)$ & $(47 \%)$ & $(76 \%)$ & $(57 \%)$ \\
\hline
\end{tabular}

Table 2

Types of null subject arguments in English and Japanese.

\begin{tabular}{|c|c|c|c|c|c|c|}
\hline & \multirow{2}{*}{$\begin{array}{l}\text { English } \\
\text { Children }\end{array}$} & \multicolumn{5}{|c|}{ Japanese } \\
\hline & & $\begin{array}{c}\text { Home } \\
\text { decoration }\end{array}$ & Mystery & Politics & Children & Total \\
\hline $1 \mathrm{st}$ & $\begin{array}{c}0 \\
(0 \%)\end{array}$ & $\begin{array}{c}0 \\
(0 \%)\end{array}$ & $\begin{array}{c}0 \\
(0 \%)\end{array}$ & $\begin{array}{c}0 \\
(0 \%)\end{array}$ & $\begin{array}{c}0 \\
(0 \%)\end{array}$ & $\begin{array}{c}0 \\
(0 \%)\end{array}$ \\
\hline $2 \mathrm{nd}$ & $\begin{array}{c}0 \\
(0 \%)\end{array}$ & $\begin{array}{c}0 \\
(0 \%)\end{array}$ & $\begin{array}{c}0 \\
(0 \%)\end{array}$ & $\begin{array}{c}0 \\
(0 \%)\end{array}$ & $\begin{array}{c}0 \\
(0 \%)\end{array}$ & $\begin{array}{c}0 \\
(0 \%)\end{array}$ \\
\hline 3rd (animate) & $\begin{array}{c}0 \\
(0 \%)\end{array}$ & $\begin{array}{c}0 \\
(0 \%)\end{array}$ & $\begin{array}{c}1 \\
(25 \%)\end{array}$ & $\begin{array}{c}0 \\
(0 \%)\end{array}$ & $\begin{array}{c}0 \\
(0 \%)\end{array}$ & $\begin{array}{c}1 \\
(4 \%)\end{array}$ \\
\hline 3rd (inanimate) & $\begin{array}{c}11 \\
(100 \%)\end{array}$ & $\begin{array}{c}10 \\
(100 \%)\end{array}$ & $\begin{array}{c}3 \\
(75 \%)\end{array}$ & $\begin{array}{c}0 \\
(0 \%)\end{array}$ & $\begin{array}{c}14 \\
(100 \%)\end{array}$ & $\begin{array}{c}27 \\
(96 \%)\end{array}$ \\
\hline Total & $\begin{array}{c}11 \\
(100 \%)\end{array}$ & $\begin{array}{c}10 \\
(100 \%)\end{array}$ & $\begin{array}{c}4 \\
(100 \%) \\
\end{array}$ & $\begin{array}{c}0 \\
(0 \%) \\
\end{array}$ & $\begin{array}{c}14 \\
(100 \%)\end{array}$ & $\begin{array}{c}28 \\
(100 \%) \\
\end{array}$ \\
\hline
\end{tabular}

Table 3

Types of null object arguments in English and Japanese.

\begin{tabular}{|l|c|c|c|r}
\hline & $\begin{array}{c}\text { Home } \\
\text { decoration }\end{array}$ & Mystery & Politics & Childr' \\
\hline Existential & 9 & 12 & 12 & 2 \\
\hline Potential & 16 & 12 & 9 & 0 \\
\hline 'Need' & 0 & 0 & 4 & 0 \\
\hline Total & 25 & 24 & 25 & 2 \\
\hline
\end{tabular}

Table 4

Number of constructions including arguably nominative-marked objects in Japanese. 


\begin{tabular}{|l|c|c|c|c|c|c|c|c|c|c|}
\hline & Home Decoration & \multicolumn{2}{|c|}{ Mystery } & \multicolumn{2}{c|}{ Japanese politics } & \multicolumn{2}{c|}{ Children } & \multicolumn{2}{c|}{ Total } \\
\cline { 2 - 10 } & English & Japanese & English & Japanese & English & Japanese & English & Japanese & English & Japanese \\
\hline \multirow{2}{*}{ Non-verbal } & 79 & 170 & 77 & 83 & 95 & 106 & 48 & 70 & 299 & 429 \\
& $(65 \%)$ & $(71 \%)$ & $(57 \%)$ & $(44 \%)$ & $(47 \%)$ & $(50 \%)$ & $(49 \%)$ & $(58 \%)$ & $(54 \%)$ & $(56 \%)$ \\
\hline \multirow{2}{*}{ Intransitive } & 22 & 61 & 57 & 103 & 24 & 80 & 48 & 51 & 151 & 295 \\
& $(18 \%)$ & $(25 \%)$ & $(42 \%)$ & $(55 \%)$ & $(12 \%)$ & $(38 \%)$ & $(49 \%)$ & $(42 \%)$ & $(27 \%)$ & $(39 \%)$ \\
\hline \multirow{2}{*}{ Passive } & 20 & 9 & 2 & 1 & 82 & 27 & 1 & 0 & 105 & 37 \\
& $(17 \%)$ & $(4 \%)$ & $(1 \%)$ & $(1 \%)$ & $(41 \%)$ & $(13 \%)$ & $(1 \%)$ & $(0 \%)$ & $(19 \%)$ & $(5 \%)$ \\
\hline \multirow{2}{*}{ Total } & 121 & 240 & 136 & 187 & 201 & 213 & 97 & 121 & 555 & 761 \\
& $(100 \%)$ & $(100 \%)$ & $(100 \%)$ & $(100 \%)$ & $(100 \%)$ & $(100 \%)$ & $(100 \%)$ & $(100 \%)$ & $(100 \%)$ & $(100 \%)$ \\
\hline
\end{tabular}

Table 5

Breakdown of one-place predicate types.

\begin{tabular}{|l|c|c|c|c|c|c|c|c|c|}
\hline & \multicolumn{3}{|c|}{ Spanish } & \multicolumn{3}{c|}{ Japanese } & \multicolumn{3}{c|}{ Turkish } \\
\cline { 2 - 11 } & Count & SD & $\%$ & Count & SD & $\%$ & Count & SD & $\%$ \\
\hline S-drop only & 19.6 & 7.5 & $99 \%$ & 3.5 & 2.1 & $69 \%$ & 20.6 & 5.5 & $96 \%$ \\
\hline SO-drop & 0 & 0.0 & $0 \%$ & 0.4 & 0.8 & $8 \%$ & 0.8 & 0.8 & $4 \%$ \\
\hline O-drop only & 0.2 & 0.4 & $1 \%$ & 1.2 & 0.8 & $24 \%$ & 0 & 0.0 & $0 \%$ \\
\hline Total & 19.8 & 7.7 & $100 \%$ & 5.1 & 2.5 & $100 \%$ & 21.4 & 6.3 & $100 \%$ \\
\hline
\end{tabular}

Table 6

Breakdown of pro-drop types: mean number of pro-drop occurrences for each category and each language (averaged across speakers).

\begin{tabular}{|l|c|c|c|c|c|c|c|c|c|}
\hline & \multicolumn{3}{|c|}{ Spanish } & \multicolumn{3}{c|}{ Japanese } & \multicolumn{3}{c|}{ Turkish } \\
\cline { 2 - 11 } & Count & SD & $\%$ & Count & SD & $\%$ & Count & SD & $\%$ \\
\hline 1st & 0 & 0.0 & $0 \%$ & 0.1 & 0.3 & $3 \%$ & 0.2 & 0.4 & $1 \%$ \\
\hline 2nd & 0.2 & 0.4 & $1 \%$ & 0 & 0.0 & $0 \%$ & 0 & 0.0 & $0 \%$ \\
\hline 3rd (animate) & 16.6 & 6.9 & $85 \%$ & 3.3 & 2.2 & $87 \%$ & 19.4 & 5.6 & $93 \%$ \\
\hline 3rd (inanimate) & 2.8 & 2.2 & $14 \%$ & 0.4 & 0.5 & $11 \%$ & 1.2 & 0.6 & $6 \%$ \\
\hline Total & 19.6 & 7.5 & $100 \%$ & 3.8 & 2.2 & $100 \%$ & 20.8 & 5.7 & $100 \%$ \\
\hline
\end{tabular}

Table 7

Breakdown of person/animacy of null subject arguments for each language (averaged across speakers). 


\begin{tabular}{|l|c|c|c|c|c|c|c|c|c|}
\hline & \multicolumn{3}{|c|}{ Spanish } & \multicolumn{3}{c|}{ Japanese } & \multicolumn{3}{c|}{ Turkish } \\
\cline { 2 - 11 } & Count & SD & $\%$ & Count & SD & $\%$ & Count & SD & $\%$ \\
\hline 1st & 0 & 0.0 & $0 \%$ & 0 & 0.0 & $0 \%$ & 0 & 0.0 & $0 \%$ \\
\hline 2nd & 0 & 0.0 & $0 \%$ & 0 & 0.0 & $0 \%$ & 0 & 0.0 & $0 \%$ \\
\hline 3rd (animate) & 0.2 & 0.4 & $100 \%$ & 1.7 & 1.5 & $94 \%$ & 0.8 & 0.8 & $100 \%$ \\
\hline 3rd (inanimate) & 0 & 0.0 & $0 \%$ & 0.1 & 0.3 & $6 \%$ & 0 & 0.0 & $0 \%$ \\
\hline Total & 0.2 & 0.4 & $100 \%$ & 1.8 & 1.5 & $100 \%$ & 0.8 & 0.8 & $100 \%$ \\
\hline
\end{tabular}

Table 8

Types of null object arguments for each language

(averaged across speakers).

\begin{tabular}{|c|c|c|c|c|c|c|c|c|}
\hline \multicolumn{3}{|c|}{ Spoken Spanish } & \multicolumn{3}{|c|}{ Spoken Mandarin } & \multicolumn{3}{|c|}{ Spoken Sacapultec Maya } \\
\hline & one-place & two-place & & one-place & two-place & & one-place & two-place \\
\hline Pro-drop & $\begin{array}{c}458 \\
(67 \%)\end{array}$ & $\begin{array}{c}331 \\
(76 \%)\end{array}$ & Pro-drop & $\begin{array}{c}130 \\
(40 \%)\end{array}$ & $\begin{array}{c}232 \\
(81 \%)\end{array}$ & Pro-drop & $\begin{array}{c}124 \\
(47 \%)\end{array}$ & $\begin{array}{c}156 \\
(87 \%)\end{array}$ \\
\hline $\begin{array}{l}\text { No-pro- } \\
\text { drop }\end{array}$ & $\begin{array}{c}227 \\
(33 \%)\end{array}$ & $\begin{array}{c}102 \\
(24 \%)\end{array}$ & $\begin{array}{l}\text { No-pro- } \\
\text { drop }\end{array}$ & $\begin{array}{c}195 \\
(60 \%)\end{array}$ & $\begin{array}{c}54 \\
(19 \%)\end{array}$ & $\begin{array}{l}\text { No-pro- } \\
\text { drop }\end{array}$ & $\begin{array}{c}138 \\
(53 \%)\end{array}$ & $\begin{array}{c}24 \\
(13 \%)\end{array}$ \\
\hline Total & $\begin{array}{c}685 \\
(100 \%)\end{array}$ & $\begin{array}{c}433 \\
(100 \%)\end{array}$ & Total & $\begin{array}{c}325 \\
(100 \%)\end{array}$ & $\begin{array}{c}286 \\
(100 \%)\end{array}$ & Total & $\begin{array}{c}262 \\
(100 \%)\end{array}$ & $\begin{array}{c}180 \\
(100 \%)\end{array}$ \\
\hline
\end{tabular}

Table 9

Pro-drop for one-place vs. two-place predicates in spoken Spanish (adopted from Bentivoglio 1992: 16),

Mandarin (adopted from Tao 1996: 116-117), and

Sacapultec Maya (adopted from Du Bois 1987: 822). 